\title{
GOSPODARKA NARODOWA
}

\section{The Polish Journal of Economics}

gnpje.sgh.waw.pl

Natalia SZOMKO*

(iD) 0000-0002-4687-9394

\section{Factors Associated with the Capital Structure of Polish Companies in the Long and Short Term}

\begin{abstract}
The aim of this article is to assess the long-term and short-term association between selected factors and the capital structure of Polish companies. In light of tradeoff theory and pecking order theory, the main factors associated with the capital structure of firms are identified. Subsequently, a set of factors associated with debt ratios is analysed on the basis of previous empirical studies. Due to the properties of data describing the capital structure, it is argued that Between and Within fixed-effects estimators can be used to assess the long- and short-term association of selected factors with the debt ratios of Polish companies. In both the long and short run, the capital structure of Polish companies is associated with profitability, the tangibility of assets, the non-debt tax shield, the tax rate, business risk, and liquidity. Growth opportunities, dividend payments, capital expenditures, and the financial deficit are only associated with debt ratios in the long term. In the short term, size and the industry median debt ratio play a significant role. The results of the study indicate that the direction and magnitude of the association of the studied factors with the debt ratios of Polish listed companies may differ between the long and short term.
\end{abstract}

Keywords: capital structure, trade-off theory, pecking order theory, debt ratio, capital structure determinants

JEL Classification Code: G32

Article submitted Septemeber 21, 2019, revision received January 19, 2020, accepted for publication January 20, 2020.

* Capital Markets Department, Collegium of World Economy, SGH Warsaw School of Economics, Poland, e-mail: natalia.szomko@sgh.waw.pl 


\section{Czynniki związane ze strukturą kapitału polskich przedsiębiorstw w długim i krótkim okresie}

Streszczenie: Celem artykułu jest ocena długoterminowej i krótkoterminowej relacji pomiędzy wybranymi czynnikami a strukturą kapitału polskich spółek giełdowych. W świetle teorii substytucji i teorii hierarchii źródeł finansowania wskazane zostały najważniejsze czynniki mające wpływ na strukturę kapitału przedsiębiorstw. Następnie analizie poddane zostały wyniki dotychczasowych badań empirycznych innych autorów w zakresie znaczenia i kierunku wpływu poszczególnych czynników. Biorąc pod uwagę charakter danych opisujących strukturę kapitału, wskazano, że estymatory efektów stałych: międzygrupowy i wewnątrzgrupowy mogą być wykorzystane do oceny długoterminowego i krótkoterminowego związku pomiędzy wybranymi czynnikami a wskaźnikami zadłużenia polskich przedsiębiorstw. Zarówno w długim, jak i w krótkim okresie z poziomem wskaźników zadłużenia polskich przedsiębiorstw związane są następujące czynniki: rentowność, materialność aktywów, tarcza podatkowa, stopa opodatkowania, ryzyko biznesowe i płynność. Ponadto stwierdzono, że możliwości rozwojowe, wypłacanie dywidend, wysokość wydatków inwestycyjnych i wielkość deficytu finansowego mają istotny związek ze wskaźnikami zadłużenia tylko w długim okresie, podczas gdy w krótkim okresie istotną rolę odgrywa wielkość przedsiębiorstwa. Wyniki badania wskazują, że kierunek i siła wpływu badanych czynników mogą się różnić w perspektywie długo- i krótkoterminowej.

Słowa kluczowe: struktura kapitału, teoria substytucji, teoria hierarchii, wskaźnik zadłużenia, determinanty struktury kapitału

Kod klasyfikacji JEL: G32

Artykuł złożony 21 września 2019 r., w wersji poprawionej nadesłany 19 stycznia 2020 r., zaakceptowany 20 stycznia $2020 \mathrm{r}$.

\section{Introduction}

The aim of this article is to assess the long-term and short-term association between selected factors and the capital structure of Polish companies. The answer to this question will contribute to a better understanding of the mechanics of the capital structure and how it changes in the case of companies listed on the Warsaw Stock Exchange.

The capital structure of companies can be described on the basis of two theories: trade-off theory and pecking order theory. The first theory stipulates that companies try to reach a target capital structure that is estimated on the basis of an analysis of the costs and benefits of additional debt. Meanwhile, the pecking order theory suggests that there exists a hierarchy of financing sources, where internal capital is the most favoured, while afterwards companies decide to use debt. External equity is only used as a last resort. As a result, if companies do not follow any target capital structure, then their decisions are not in line with the trade-off theory.

According to the trade-off theory, changes to the capital structure of companies are driven by attempts to reach the target capital structure. The pecking order theory stipulates that the capital structure of a company is the result of 
previous decisions about the choice of financing sources. In both cases, there should be a difference in the magnitude (and perhaps direction) of the association of selected factors with the capital structure of companies analysed in the long and short term. The financial situation of a company is affected by numerous circumstances that can change in the long or short term. Although companies may not adjust their current capital structure to the target, such an effect may be confused with differences in the mechanics of the long- and short-run association of the capital structure and selected factors.

An ample number of studies have examined factors associated with the capital structure. Most of them focus on either the association of selected factors with the current capital structure of companies or the identification of factors associated with the capital structure and target debt ratios. The list of factors claimed to be associated with the values of the current debt ratios of companies is long, though they focus on the short term. Nonetheless, as Lemmon et al. [2008] point out, the debt ratios of companies are persistent over time, and the historical values of the debt ratios have a significant association with the current capital structure even after traditional factors included in capital structure research are taken into account.

The set of factors associated with the capital structure identified in previous studies may relate differently to the capital structure of companies in the long and short run. For this reason, the long- and short-term association of these factors and debt ratios is estimated with the use of fixed-effects estimators. The results show that in the long run, the size of a company is positively associated with the debt ratios, while growth opportunities, profitability and the non-debt tax shield are negatively associated. In the short run, size, the tangibility of assets and the industry median debt ratio have a positive association with the debt ratios, while profitability and the non-debt tax shield are negatively related.

The rest of the paper is organised as follows. In the first part, the trade-off theory is described and compared with the pecking order theory. In the second part, the main results of previous empirical research on the target capital structure and adjustment speeds are discussed. The next part elaborates on the need to differentiate between the long- and short-term associations of the identified factors with the debt ratios. This is followed by a description of the data and methods used in this study. The next part presents the estimation results, i.e. factors associated with the capital structure of Polish companies in the long and short term. The last section concludes.

\section{Theories of capital structure}

The capital structure of companies is described on the basis of two main theories: the trade-off theory and the pecking order theory. These theories differ not only in the suggested mechanisms of capital structure decisions, but also in the set of factors associated with the capital structure. 
According to the trade-off theory, the goal of financial policy for a company's managers is to achieve an optimal capital structure that maximises the company's value [Huang, Ritter, 2009]. The optimal capital structure balances the costs and benefits of additional debt. On the one hand, a higher value of debt results in a higher value of the debt tax shield, which diminishes the tax liabilities of the company. On the other hand, greater debt increases the direct and indirect costs of financial distress, while negatively influencing the company's financial elasticity and its ability to pay dividends. As the value of the costs and benefits cannot be precisely calculated, the managers focus on the target capital structure.

Theoretical models built on the basis of trade-off theory assumptions pay special attention to factors such as tax advantages [Stiglitz, 1973; Strebulaev, 2007], bankruptcy costs [Bradley et al., 1984; Strebulaev, 2007], profitability [Brennan, Schwartz, 1978; Strebulaev, 2007], size [Fischer, Heinkel, Zechner, 1989], the non-debt tax shield [Bradley et al., 1984], business risk [Leland, 1994; Miao, 2005], the uniqueness of products [Strebulaev, 2007], growth opportunities [Brennan, Schwartz, 1978], and net investment [Brennan, Schwartz, 1978]. In light of the trade-off theory, the following factors are negatively associated with the target capital structure: growth opportunities, R\&D expenditures, the non-debt tax shield, business risk, the probability of bankruptcy, capital expenditures, and the uniqueness of a product. Meanwhile, factors such as profitability, size, the tangibility of assets, liquidity, asset turnover, and business risk are positively associated with the capital structure.

Taking into consideration the target debt ratio, it is important to differentiate between two versions of the trade-off theory. A static trade-off theory stipulates that adjustment to the target capital structure is made in every period. The target capital structure may be constant for the company, but it is also possible that it changes with the situation of the company [Fischer, Heinkel, Zechner, 1989; Leland, 1994] or that there may not exist a single target capital structure, but rather a range of target capital structures [Fischer, Heinkel, Zechner, 1989; Titman, Tsyplakov, 2007]. Consequently, significant changes in the values of factors associated with the target capital structure can lead to changes in both the target capital structure and the size of the adjustment necessary for the capital structure to lie within the target range.

Another issue worth considering is the frequency of capital structure adjustments. According to the dynamic trade-off theory, the costs of capital structure adjustments have to be taken into account [Hamada et al., 1984; Fischer, Heinkel, Zechner, 1989; Roberts, Leary, 2004; Strebulaev, 2007; Titman, Tsyplakov, 2007]. The theoretical models listed above conclude that, due to the existence of these costs, companies do not adjust their capital structure in every period. An adjustment will only take place when the discrepancy between the actual and target capital structures is large enough to justify the costs of such an adjustment. The costs in question are higher when the debt ratio is higher than its target [Hamada et al., 1984]. Nonetheless, 
due to similarities in adjustment criteria, the capital structure of companies should change over time in a similar manner [Leland, 1994].

The second capital structure theory - the pecking order theory - holds that managers have strict preferences for financing sources [Myers, 1984; Myers, Majluf, 1984]. A company's operations are financed first with internal sources (retained earnings and cash and its equivalents). Then managers increase external financing, while debt is preferred to equity. As a consequence, the capital structure is the result of previous choices of financing sources, and an optimal capital structure does not exist.

The presented order of financing sources is the result of an information asymmetry between the stakeholders and the managers [Roberts, Leary, 2010]. The managers prefer sources that are safer and the value of which changes less if the managers make public information that may influence the stakeholders' perception of the company's value. The static version of pecking order theory stipulates the permanence of preferences. According to the dynamic version of the theory, preferences may change in response to changes in the situation on capital markets or changes in the company's valuation [Lucas, McDonald, 1990].

Theoretical models built on the basis of the pecking order theory do not directly list factors associated with the capital structure of companies. They rather focus on the decision about the choice between sources of financing. However, considering that, according to this theory, the current capital structure of a company is a result of previous decisions, and it is possible to list factors associated with the capital structure and identify the direction of their relation. Profitability and liquidity should be negatively associated with the debt ratios of companies: the more profit and cash a company has, the less debt it is willing to use. The association of size with the debt ratios is expected to be positive, as larger companies use more debt financing due to greater information asymmetry.

As far as the tangibility of assets is concerned, its negative association with the debt ratios is motivated by the fact that companies with a higher share of tangible assets face lower information asymmetry. The financial deficit should be positively associated with the debt ratios: the higher the deficit, the more external capital is needed to pursue investment projects. Capital expenditures should have a positive association with the debt ratios: the higher the value of the current investment projects of a company, the more external capital is needed to finance them. Moreover, according to the dynamic version of the pecking order theory, growth opportunities should also be positively associated with the debt ratios, as the managers may be willing to use more external financing for current projects when they predict that future investments may require more outlays, thus leaving more internal financing available for the future. The same holds for business risk, as greater variability of results leads managers to save more internal resources for the future. Also, if a company pays dividends, then its requirements for financing are greater, which creates a positive association with the debt ratios. 
To sum up, the list of factors associated with the capital structure according to the trade-off theory and the pecking order theory varies significantly. The predicted direction of the relation between the factors and debt ratios differs for profitability, growth opportunities, asset tangibility, liquidity and capital expenditures.

\section{Results of empirical research on capital structure determinants}

Several research questions can be distinguished in previous studies into the mechanics of the capital structure. First, a significant number of studies focus on factors associated with the current capital structure of companies. Second, various researchers have analysed factors associated with the target capital structure and adjustment of the actual capital structure to the target. There are also several studies based on simulated and empirical data that aim to assess the ability of currently used statistical methods to describe the mechanics of the capital structure among companies. Information on the capital structure obtained on the basis of company financial data is complemented by the results of surveys of managers in companies operating in both the United States and Europe.

The surveys show that most American and European managers claim to have a target capital structure [Graham, Harvey, 2001; Bancel, Mittoo, 2004; Brounen, de Jong, Koedjik, 2006]. However, these studies do not precisely state how the target capital structure is defined and do not provide information on the understanding of this term by the managers. Therefore, on the basis of these results, it cannot be firmly concluded that the behaviour of companies is in line with the trade-off theory.

For the purpose of this study, it is necessary to identify the set of factors documented to be associated with the target capital structure. Factors analysed in selected studies are presented in Table 1.

Most of the reviewed studies analyse the following determinants: growth opportunities, profitability, size, and the tangibility of assets. These factors were identified as the most important in the seminal paper of Rajan and Zingales [1995]. Researchers do not agree on the direction of the relationship between growth opportunities and the tangibility of assets, on the one hand, and the target debt ratios, on the other. Profitability is negatively associated with the target capital structure, while the association of size with the debt ratios is positive. Among other variables presented in the table, the median industry debt ratio and the debt rating have a positive association with the target capital structure, while the non-debt tax shield, R\&D expenditures, dividends and liquidity are negatively related. Existing studies do not agree on the direction of the relationship between the tax rate and business risk.

The list of variables in Table 1 is not exhaustive. Other variables included in previous studies include the probability of bankruptcy [Dang, Garret, 2015], capital expenditures [Dang, Kim, Shin, 2012], the financial deficit [Dang, Kim, 
Shin, 2012], corporate governance standards [Chang, Chou, Huang, 2014], macroeconomic variables [Oztekin, Flannery, 2012], and the institutional environment [Nivorozhkin, 2005].

Table 1. Capital structure determinants analysed in previous empirical research

\begin{tabular}{|c|c|}
\hline Variable & Selected studies \\
\hline $\begin{array}{l}\text { growth } \\
\text { opportunities }\end{array}$ & $\begin{array}{l}\text { Arioglu, Tuan [2014], Brendea [2014], Chang, Chou, Huang [2014], Dang, Garret } \\
\text { [2015], Dang, Kim, Shin [2012], Dang, Kim, Shin [2014], Farhat, Cotei, Abugri [2006], } \\
\text { Faulkender et al. [2012], Flannery, Rangan [2006], Lemma, Negash [2014], Lemmon, } \\
\text { Roberts, Zedner [2008], Lockhart [2014], Matemilola et al. [2015], Oino, Ukaegbu [2015], } \\
\text { Ozkan [2001], Oztekin, Flannery [2012] }\end{array}$ \\
\hline profitability & $\begin{array}{l}\text { Arioglu, Tuan [2014], Brendea [2014], Chang, Chou, Huang [2014], Dang, Garret } \\
\text { [2015], Dang, Kim, Shin [2012], Dang, Kim, Shin [2014], Farhat, Cotei, Abugri [2006], } \\
\text { Faulkender et al. [2012], Flannery, Rangan [2006], Lemma, Negash [2014], Lemmon, } \\
\text { Roberts, Zedner [2008], Lockhart [2014], Matemilola et al. [2015], Oino, Ukaegbu [2015], } \\
\text { Ozkan [2001], Oztekin, Flannery [2012] }\end{array}$ \\
\hline size & $\begin{array}{l}\text { Arioglu, Tuan [2014], Brendea [2014], Chang, Chou, Huang [2014], Dang, Garret } \\
\text { [2015], Dang, Kim, Shin [2012], Dang, Kim, Shin [2014], Farhat, Cotei, Abugri [2006], } \\
\text { Faulkender et al. [2012], Flannery, Rangan [2006], Lemma, Negash [2014], Lemmon, } \\
\text { Roberts, Zedner [2008], Lockhart [2014], Matemilola et al. [2015], Oino, Ukaegbu [2015], } \\
\text { Ozkan [2001], Oztekin, Flannery [2012] }\end{array}$ \\
\hline $\begin{array}{l}\text { tangibility of } \\
\text { assets }\end{array}$ & $\begin{array}{l}\text { Arioglu, Tuan [2014], Brendea [2014], Chang, Chou, Huang [2014], Dang, Garret } \\
\text { [2015], Dang, Kim, Shin [2012], Dang, Kim, Shin [2014], Farhat, Cotei, Abugri [2006], } \\
\text { Faulkender et al. [2012], Flannery, Rangan [2006], Lemma, Negash [2014], Lemmon, } \\
\text { Roberts, Zedner [2008], Lockhart [2014], Matemilola et al. [2015], Oino, Ukaegbu [2015], } \\
\text { Oztekin, Flannery [2012] }\end{array}$ \\
\hline $\begin{array}{l}\text { non-debt tax } \\
\text { shield }\end{array}$ & $\begin{array}{l}\text { Chang, Chou, Huang [2014], Dang, Garret [2015], Dang, Kim, Shin [2012], Dang, Kim, } \\
\text { Shin [2014], Farhat, Cotei, Abugri [2006], Faulkender et al. [2012], Flannery, Rangan } \\
\text { [2006], Lockhart [2014], Matemilola et al. [2015], Ozkan [2001], Oztekin, Flannery [2012] }\end{array}$ \\
\hline $\begin{array}{l}\text { median industry } \\
\text { debt ratio }\end{array}$ & $\begin{array}{l}\text { Arioglu, Tuan [2014], Chang, Chou, Huang [2014], Dang, Garret [2015], Dang, Kim, Shin } \\
\text { [2014], Faulkender et al. [2012], Flannery, Rangan [2006], Lemmon, Roberts, Zedner } \\
\text { [2008], Lockhart [2014], Oztekin, Flannery [2012] }\end{array}$ \\
\hline $\begin{array}{l}\text { R\&D } \\
\text { expenditures }\end{array}$ & $\begin{array}{l}\text { Chang, Chou, Huang [2014], Dang, Garret [2015], Dang, Kim, Shin [2014], Faulkender } \\
\text { et al. [2012], Flannery, Rangan [2006], Lockhart [2014], Oztekin, Flannery [2012] }\end{array}$ \\
\hline dividends & Dang, Garret [2015], Lemma, Negash [2014], Lemmon, Roberts, Zedner [2008] \\
\hline tax rate & Dang, Garret [2015], Oino, Ukaegbu [2015], Oztekin, Flannery [2012] \\
\hline business risk & Lemma, Negash [2014], Lemmon, Roberts, Zedner [2008] \\
\hline debt rating & Chang, Chou, Huang [2014], Flannery, Rangan [2006] \\
\hline liquidity & Ozkan [2001], Oztekin, Flannery [2012] \\
\hline
\end{tabular}

Source: own work.

As far as previous research for companies operating in Poland is concerned, the results are similar to those described above. The debt ratios of Polish companies are associated with profitability [Gajdka, 2003; Mazur, 2007; Joever, 2012, Białek-Jaworska, Nehrebecka, 2015], growth opportunities [Klapper et al., 2006], size [Klapper et al., 2006; Joever, 2012; Mazur, 2007], the tangibility of assets [Klapper et al., 2006; Joever, 2012, Gajdka, 2002], the non-debt 
tax shield [Gajdka, 2002; Mazur, 2007], liquidity [Gajdka, 2002; Mazur, 2007], and dividends [Mazur, 2007].

According to previous studies, most of the variability of the debt ratios can be explained on the basis of factors characteristic of companies [Balkrishnan, Fox, 1993; Kayo, Kimura, 2011; Joever, 2012]. However, the variability of factors associated with the capital structure used in previous empirical research by other authors has limited power to explain the variability of the observed debt ratios [Lemmon, Roberts, Zender, 2008; Frank, Goyal, 2005]. Apart from the existence of omitted variables, this may be due to the omission of long-term relations between the selected factors and the capital structure in the model specification.

To sum up, previous studies have identified numerous factors associated with the capital structure. The results of previous research by other authors agree on neither the direction nor magnitude of the relationship between these factors and the debt ratios. Nevertheless, their association with the debt ratios of companies was analysed only in the short term, focusing on the relation between the financial situation of companies in the previous period and their debt ratios at the end of the analysed period.

\section{Long-term capital structure analysis}

The need for an analysis of the long-term association of the identified factors with company debt ratios can be motivated by the implications of capital structure theories, as well as in light of the properties of panel data and available estimation methods.

The trade-off theory stipulates that the target capital structure is assessed on the basis of the costs and benefits of additional debt. However, neither the costs nor the benefits can be measured on the basis of company financial data. Even if researchers had access to the internal data of companies, the measurement of the tax benefits or costs of bankruptcy would have to be based on a wide set of assumptions that could not be verified ex ante. Moreover, the target capital structure may be defined not only as a specific debt ratio, but also as a range of debt ratios. The target capital structure of a company is expected to change frequently as a consequence of changes in the financial condition of the company and its economic environment. As a consequence, any attempt to explain adjustments in the current capital structure of a company to the target capital structure is highly sensitive to changes in the financial situation of the company not related to capital structure decisions.

As far as the pecking order theory is concerned, the choice of financing sources is not observed on a discrete basis. The amount of debt used by a company changes not only as a consequence of specific decisions, but also due to a lack of them: without incurring any additional debt, the debt ratio of a company will decrease due to the payment of instalments. Moreover, if the company generates profit and does not pay dividends, then the use of inter- 
nal sources of financing will result in lower debt ratios. It could therefore be expected that even if the company follows the pecking order theory in its decisions, most of the changes in the debt ratios may not be related to specific decisions, but rather be a consequence of standard business operations.

Previous empirical research includes several studies that look at how current methods make it possible to distinguish the behaviour of companies attempting to follow the pecking order theory and the trade-off theory. The capital structure has a tendency for mean reversion, which may lead to an unjustified conclusion that an adjustment towards the target capital structure is observed [Shyam-Sunder, Myers, 1999; Chang, Dasgupta, 2009]. Moreover, the significant association of the factors suggested by the trade-off theory with the capital structure can be observed even if the company attempts to follow the pecking order theory, as the factors in question are associated with the retained earnings and the financial deficit of the company [Shyam-Sunder, Myers, 1999; Chang, Dasgupta, 2009]. When the actual financial data of companies (such as the financial deficit, retained earnings, and the probability distributions of the choices of financing sources) are combined with simulated data on the current debt ratios of companies (generated randomly on the basis of the probability distributions observed in the actual data), then the changes in the actual debt ratios are best imitated when the assumed speed of adjustment towards the target capital structure is low, i.e. between $10 \%$ and $20 \%$ [DeAngelo, Roll, 2015]. Moreover, with such a low adjustment speed, it is impossible to clearly state if the target capital structure of the companies is stable or changes over time [DeAngelo, Roll, 2015]. The results of these studies prove that the observed changes in the capital structure of companies do not enable researchers to confirm the existence of the target capital structure, and the reason behind the alleged adjustment towards the target capital structure may be a mean-reversion process.

The pecking order theory and the trade-off theory focus on more than just short-term capital structure decisions. In particular, a set of factors associated with the debt ratios of the companies according to the pecking order theory is identified as a result of the consecutive choices of sources of financing in accordance with this theory. According to the trade-off theory, the capital structure changes only if the difference between the current and target ratios is high enough to justify the costs of adjustment, while the adjustment is expected to last for several periods. Therefore, the trade-off theory also does not focus on one-period adjustments, but rather on attempts to explain the mechanics of the capital structure over a longer time horizon.

Factors associated with the capital structure of companies are analysed on the basis of panel data, with a large cross-sectional dimension and a short time dimension. Moreover, apart from two-dimensional residuals, the data have two important characteristics that need to be taken into account: the persistence of the dependent variable and the endogeneity of independent variables [Baltagi, 2008]. 
Two-dimensional residuals and the endogeneity of explanatory variables, i.e. their correlation with the residuals, require researchers to use estimation methods that are suitable for their inclusion, i.e. fixed-effects estimators or generalised-method-of-moments estimators. As a consequence, the estimation of more advanced specifications such as an error-correction model is not available with these estimators. At the same time, the short time dimension of the data results in a limited possibility of including the lagged distribution of explanatory variables, which would be the most adequate for measuring the long-term association of selected factors with the debt ratios. For example, for companies listed on the Warsaw Stock Exchange, the average number of years with data is smaller than eight, while the number of years needed to adjust the capital structure fully to its target is higher than 8.3, assuming the speed of adjustment estimated for Poland in previous studies by other authors of between $0 \%$ and 12\% [Nivorozhkin, 2005; de Haas, Peeters, 2004]).

Taking into account the high persistence of the debt ratios, in the dynamic specification of the regression models, a lagged dependent variable is usually used as one of the explanatory variables [Flannery, Hankins, 2013; Roodman, 2006]. It may be argued that the long-run association of the selected factors with the capital structure is already consumed in the model by the inclusion of this variable. However, there are several reasons for which such a handling of long-term relations may not be sufficient. First, the inclusion of the lagged dependent variable influences the properties of the estimators, resulting in biased estimates for the parameter for lagged dependent variables when using ordinary least-squares or fixed-effects estimators. Second, this does not enable researchers to identify the direction and magnitude of the association of selected factors with the capital structure in the long term. Third, the lagged debt ratio, as one of the explanatory variables, describes not only the long-term association of the identified factors associated with the capital structure, but also a significant part of the unobserved variables such as managerial ability [Ang, Cole, Lawson, 2010; Matemilola et al., 2015].

Decisions influencing the debt ratio of companies at the end of the current period are made simultaneously with decisions shaping the profitability of a company, its liquidity, non-debt tax shield, business risk, capital expenditures, financial deficit, etc. Therefore, econometric models used in previous studies focused on the association of selected factors in the previous period with the debt ratios in the current period, which does not fully reflect the short-term relation.

To sum up, the specification of models of factors associated with the capital structure used in previous studies by other authors is limited by the properties of financial data available for the analysis, and the main focus is the association of the financial situation of a company in the previous period with its debt ratio at the end of the current period. An attempt to compare the association of selected factors with the capital structure in the long term and in the short term might be an important step towards understanding the mechanism of shaping company capital structures. 


\section{Data and methodology}

The aim of this article is to assess the long-term and short-term association between selected factors and the capital structure of Polish companies. The sample consists of companies listed on the Warsaw Stock Exchange from 2002 to 2015. Due to industry-specific financing sources, the sample excludes companies in the following industries: banking, the capital market, conglomerates, insurance and other financial. The sample only includes companies with the Polish zloty as their reporting currency. There are 3,094 observations in the sample for 426 companies.

The dependent variable for the study is the total debt ratio, defined as the ratio of the book value of liabilities to the sum of the book value of liabilities and the market value of equity. The explanatory variables include growth opportunities, profitability, size, the tangibility of assets, the non-debt tax shield, the industry median debt ratio, dividend payments, the tax rate, business risk, liquidity, capital expenditures, and the financial deficit. Growth opportunities are measured as the ratio of the market value of equity to the book value of equity. Profitability is measured as the ratio of operating income to total assets. Size is measured as the natural logarithm of total assets. The tangibility of assets is measured as the ratio of fixed assets to total assets. The non-debt tax shield is measured as the ratio of depreciation and amortisation to total assets. The industry median debt ratio is calculated for every industry in every year. The payment of dividends is included in the study with a dummy variable equal to 1 if the company paid dividend in the year in question and 0 otherwise. The tax rate is calculated as the ratio of tax liability in the year in question to earnings before taxes. Business risk is defined as the standard deviation of the return on assets over a three-year period. Liquidity is measured as the ratio of cash and cash equivalents to total assets. Capital expenditures are included in the study as the ratio of capital expenditures to total assets. The financial deficit is calculated as follows: (- cash flow from operations + net investment + dividends - change in cash + change in working capital)/market value of equity.

The properties of the panel data described above limit the use of generalised-method-of-moments (GMM) estimators and fixed-effects estimators. Nonetheless, GMM estimators are not designed to differentiate between the long-term and short-term relations [Ruiz, 2016]. When it comes to fixed-effects estimators, the Between estimator (BE) can be used to obtain long-run estimates, whereas the Within estimator (used as the default fixed-effects estimator, therefore called FE) can be used to obtain short-run estimates [Baltagi, 2008; Ruiz, 2016]. In order to estimate the long-term association of selected factors and the capital structure, a regression model is estimated with the BE estimator. For the short-run association of the same set of variables, the FE estimator is used. 
The model estimated by the FE estimator has the following specification:

$$
y_{i t}=X_{i t} \beta+u_{i t}
$$

where $y_{i t}$ is a vector of dependent variable, $X_{i t}$ is a matrix of independent variables, $\beta$ is the vector of parameter estimates, while $u_{i t}$ is the two-dimensional error term [Baltagi, Griffin, 1984]. The BE estimator is obtained by regressing on individual means, while its specification can be presented as follows:

$$
\bar{y}_{i \cdot}=\bar{X}_{i \cdot} \beta+\bar{u}_{i \cdot}
$$

where $\bar{y}_{i}$ is the vector of the average values of dependent variables across time, $\bar{X}_{i}{ }_{i \cdot}$ is the matrix of the average values of independent variables across time, $\beta$ is the vector of parameter estimates, while $\bar{u}_{i}$ is the error term [Baltagi, Griffin, 1984].

The differences in the estimation results between the BE and the FE estimators were noticed in the studies of, among others, Kuh [1959] and Houtakker [1965]. As argued by Baltagi [2008], the differences between BE and FE parameter estimates are often considered a result of various misspecification problems. A number of studies indicate that the difference in the parameter estimates in question is a result of an omission of important explanatory variables [Mundlak, 1978] or measurement errors in the explanatory variables [Grilliches, Hausman, 1986; Mairesse, 1990]. However, it can also be argued that, in a dynamic framework, the differences in question may result from the fact that the $\mathrm{BE}$ estimator focuses on the long-term effect of the explanatory variables [Pirotte, 1999; Baltagi, Griffin, 1984]. This conclusion is based on the observation that "cross sections typically will reflect long run adjustments whereas annual time series will tend to reflect shorter run reaction" [Kuh, 1959].

Previous studies show that the use of the BE estimator gives similar results if, instead of the levels of explanatory variables, its "means for the individuals" are used, while the FE estimator yields similar results if the deviations from "means for the individuals" are used as an explanatory variable instead of its levels [Ruiz, 2016]. Therefore, a lagged dependent variable should not be included in the regression specification estimated with the BE estimator. For the FE estimator, it is possible to include the lagged dependent variable as one of the explanatory variables, though its parameter estimate is biased [Baltagi, 2008].

\section{The results of the study}

The table below presents the results of the models describing the association between selected factors with the capital structure of Polish companies in the long and short term.

In order to assess the association in question in the long run, Model I was estimated with the BE estimator with robust standard errors. The regression 
model included fixed effects for years. The association of selected factors with the capital structure in the short run was analysed with the use of Model II, estimated with the FE estimator with robust standard errors. This specification also included fixed effects for years and a lagged dependent variable as one of the explanatory variables.

Table 2. The results of parameter estimates (and their standard errors in parentheses) for capital structure models estimated with different estimation methods with basic model characteristics.

\begin{tabular}{|c|c|c|c|c|}
\hline & \multicolumn{2}{|c|}{ ModelI } & \multicolumn{2}{|c|}{ ModelII } \\
\hline estimation method & \multicolumn{2}{|l|}{$\mathrm{BE}$} & \multicolumn{2}{|c|}{$\mathrm{FE}$} \\
\hline lagged debt ratio & & & $\begin{array}{c}0.4185 \\
(0.0241)\end{array}$ & $* * *$ \\
\hline growth opportunities & $\begin{array}{l}-0.0009 \\
(0.0003)\end{array}$ & $* * *$ & $\begin{array}{l}-0.0003 \\
(0.0005)\end{array}$ & \\
\hline profitability & $\begin{array}{l}-0.7799 \\
(0.0959)\end{array}$ & $* * *$ & $\begin{array}{l}-0.0582 \\
(0.0142)\end{array}$ & $* * *$ \\
\hline size & $\begin{array}{c}0.0300 \\
(0.0062)\end{array}$ & & $\begin{array}{c}0.0270 \\
(0.0088) \\
\end{array}$ & $* * *$ \\
\hline tangibility of assets & $\begin{array}{l}-0.1011 \\
(0.0498)\end{array}$ & $* *$ & $\begin{array}{c}0.1233 \\
(0.0364)\end{array}$ & $* * *$ \\
\hline non-debt tax shield & $\begin{array}{l}-0.6473 \\
(0.3148)\end{array}$ & $* *$ & $\begin{array}{l}-0.2559 \\
(0.0637)\end{array}$ & $* * *$ \\
\hline industry median debt ratio & $\begin{array}{c}0.1387 \\
(0.2265)\end{array}$ & & $\begin{array}{c}0.0375 \\
(0.0382)\end{array}$ & \\
\hline dividends & $\begin{array}{l}-0.1373 \\
(0.0332)\end{array}$ & $* * *$ & $\begin{array}{c}0.0028 \\
(0.0079)\end{array}$ & \\
\hline tax rate & $\begin{array}{l}-0.0013 \\
(0.0005)\end{array}$ & $* *$ & $\begin{array}{l}-0.0004 \\
(0.0001)\end{array}$ & $* * *$ \\
\hline business risk & $\begin{array}{l}-0.3850 \\
(0.0956)\end{array}$ & *** & $\begin{array}{c}0.0455 \\
(0.0149)\end{array}$ & $* * *$ \\
\hline liquidity & $\begin{array}{c}-0.4163 \\
(0.0806)\end{array}$ & *** & $\begin{array}{l}-0.0650 \\
(0.0365)\end{array}$ & $*$ \\
\hline capital expenditures & $\begin{array}{r}-0.4539 \\
(0.1770) \\
\end{array}$ & $* *$ & $\begin{array}{c}0.0774 \\
(0.0498) \\
\end{array}$ & \\
\hline financial deficit & $\begin{array}{c}0.0126 \\
(0.0076) \\
\end{array}$ & * & $\begin{array}{c}0.0006 \\
(0.0007)\end{array}$ & \\
\hline constant & $\begin{array}{c}0.1145 \\
(0.1651) \\
\end{array}$ & & $\begin{array}{l}-0.2528 \\
(0.1195) \\
\end{array}$ & $* *$ \\
\hline number of observations & 3074 & & 3074 & \\
\hline $\mathrm{R} 2$ & 0.2371 & & 0.3831 & \\
\hline
\end{tabular}

*** significant at 0.01 level $* *$ significant at 0.05 level * significant at 0.1 level

Source: own work.

The parameter for the lagged debt ratio was only included in Model II. The parameter estimate confirms the conclusions of previous studies that the 
lagged dependent variable is one of the most important factors associated with the debt ratios of companies.

Growth opportunities are significantly associated with the debt ratio only in the long-run model (Model I). The larger the growth opportunities of the company, the lower its debt ratio in the long run. The results are not in line with the trade-off theory, but support the pecking order theory. Moreover, the direction of the relation between this factor and the debt ratio is consistent with the results of previous studies.

Profitability has a significantly negative association with the total debt ratio in both models. However, the magnitude of this association in the longrun model (Model I) is almost seven times higher than the short-run effect in Model II. The negative relation of this variable with the debt ratio is often claimed to be in line with the pecking order theory. However, it is also possible to explain such a direction of relation with the dynamic trade-off theory [Strebulaev, 2007]. The negative association of profitability and the debt ratio was also confirmed by previous studies.

Size is significantly positively associated with the total debt ratio according to Model II. In the short term, the higher the value of the company's total assets, the higher is its total debt ratio. The positive relation between size and the capital structure supports both the trade-off theory and the pecking order theory, and it is also confirmed by previous studies.

The association of the tangibility of assets with the total debt ratio is positive in the short term, but negative in the long-run specification. A higher tangibility of assets is related to a higher total debt ratio in the short term. At the same time, in the long term, a higher tangibility of assets is associated with lower debt ratios. The positive association of this factor with the dependent variable is not only predicted by the trade-off theory, but was also reported in previous studies.

The non-debt tax shield has a significant negative association with the total debt ratio for both models. The magnitude of this relation is higher in the long term. The direction of the association of the non-debt tax shield with the debt ratio is in line with the trade-off theory, while previous studies do not agree on the direction of this relation.

The association of the industry median debt ratio with the total debt ratio was not statistically significant.

The payment of dividends is only associated with the capital structure in the long term, and the direction of this relation is negative. Companies paying dividends have lower debt ratios in the long run. Such a relation is consistent with the results of previous studies.

The variable describing the tax rate has a significantly negative association with the capital structure in both the long and short term. The higher is the company's tax rate, the lower is its debt ratio. The magnitude of the association between the tax rate and the debt ratio is more pronounced in the long term. The observed direction of the association does not support the tradeoff theory, while the results of empirical studies were mixed for this factor. 
The association between business risk and the debt ratio was negative in the long run, while being positive in the short run. The difference in this association for Polish companies is visible not only in the direction of the relation, but also in its magnitude, which is five times higher for the long-run relation. Both the trade-off theory and the pecking order theory suggest that a higher business risk should lead to a decrease in the debt ratios, which is in line with the results of this study for the long term. Previous research does not agree on the direction of association between this factor and debt ratios.

Liquidity has a significantly negative association with the debt ratios of Polish companies in both the short and long run, while the magnitude of the short-term association is much higher than the magnitude of the long-term association. Companies with higher liquidity have lower debt ratios. The direction of the relation is in line with the predictions of the pecking order theory, but contrary to the trade-off theory. A negative association of liquidity with debt ratios was also observed in previous research.

The association between capital expenditures and the capital structure is significantly negative in the long run. Higher capital expenditures result in lower debt ratios in the long term. This is in accordance with the predictions of the trade-off theory, but contrary to the pecking order theory. Moreover, the results of previous research do not agree on the direction of association between this factor and debt ratios.

The positive association of the financial deficit and debt ratios was only observed in the long run. Companies with higher financial deficits can be expected to have higher debt ratios in the long term. This is in line with the predictions of the pecking order theory as well as with the results of previous studies.

In the long run, the capital structure of the Polish companies is associated with growth opportunities, profitability, the tangibility of assets, the nondebt tax shield, dividend payments, the tax rate, business risk, liquidity, capital expenditures, and the financial deficit. Companies with greater growth opportunities may have lower debt ratios due to a higher information asymmetry (according to the pecking order theory) or higher costs of bankruptcy (according to the trade-off theory). More profitable companies use less debt, which may be associated with the higher value of internal sources of financing (according to the pecking order theory) or less frequent capital structure adjustments (according to the dynamic trade-off theory). The negative association of asset tangibility with debt ratios may be explained on the basis of lower sensitivity to the information asymmetry (according to the pecking order theory). Companies with a higher non-debt tax shield have lower debt ratios due to the lower need for a tax shield resulting from higher debt (according to the trade-off theory). Companies paying dividends have lower debt ratios, which is not in line with the capital structure theories. A higher tax rate is associated with lower debt ratios, which does not find support in existing theories. The negative association of business risk with company debt ratios may be a consequence of greater asymmetry of information faced by these com- 
panies (according to the pecking order theory) or increased costs of financial distress (according to the trade-off theory). Companies with higher liquidity have lower debt ratios due to higher financing needs (according to the pecking order theory). Higher capital expenditures are also associated with lower debt ratios, which may stem from higher financing needs (according to the pecking order theory) or from an expected rise in the costs of financial distress (according to the trade-off theory). The positive association of the financial deficit with debt ratios supports the view that these companies have higher financing needs (according to the pecking order theory).

In the short term, the factors associated with the capital structure of Polish companies are the debt ratio in the previous period, profitability, size, the tangibility of assets, the non-debt tax shield, tax rate, business risk and liquidity. The capital structure of Polish companies in the short term is not associated with changes in growth opportunities, dividend payments, capital expenditures and the financial deficit, which were proved to be associated with the debt ratios in the long run. Moreover, the association between size and debt ratios is only observed in the short term. Companies with a higher value of assets have higher debt ratios, which may be due to greater information asymmetry (according to the pecking order theory) or lower costs of financial distress (according to the trade-off theory).

To sum up, factors associated with the capital structure identified in previous studies are significantly associated with the capital structure of Polish companies in both the long and short run. In both cases, debt ratios are significantly associated with profitability, the tangibility of assets, the non-debt tax shield, the tax rate, business risk, and liquidity. Growth opportunities, capital expenditures and the financial deficit are significantly associated with debt ratios only in the long term, while the association with size is only significant in the short term. The tangibility of assets and business risk are negatively associated with debt ratios in the long run, while being positively associated in the short run. Moreover, in the long term, factors such as profitability, the non-debt tax shield, dividend payments, the tax rate, business risk and liquidity have a more pronounced association with the capital structure of Polish companies than in the short term.

\section{Conclusion}

The aim of this article was to assess the long- and short-term association of selected factors with the capital structure of Polish companies. The set of factors assumed to be associated with the capital structure of companies differs according to the trade-off theory and the pecking order theory. Moreover, the theories in question do not always agree on the direction of this relation. After a thorough review of the capital structure theories, the results of previous studies were presented. Special attention was paid to the identified factors, which are related to the capital structure, and to the direction of their association with company debt ratios. 
To analyse the observed differences in the association of selected factors with the capital structure in the long and short term, models explaining the total debt ratios of the Polish companies were estimated. The BE estimator was used to describe the long-run relations, while the FE estimator was applied to quantify the short-run relations. The results of this study confirm that not only the set of factors associated with the capital structure of the Polish companies differs in the long term and short term, but also the magnitude and direction of this association may be different. In the long term, total debt ratios are positively associated with the financial deficit, while being negatively associated with growth opportunities, profitability, asset tangibility, the non-debt tax shield, dividend payments, the tax rate, business risk, liquidity and capital expenditures. In the short term, total debt ratios are positively associated with size, the tangibility of assets, and business risk, while being negatively associated with profitability, the non-debt tax shield, the tax rate, and liquidity. The magnitude of the association and its direction may differ between the long and short term.

The most important limitations of this study are a limited set of factors included in the analysis and the focus on Polish companies. Therefore, future research could include a larger set of factors that can possibly be associated with the total debt ratios, including institutional factors and macroeconomic variables. Moreover, it would be advisable to repeat the study on the basis of a sample of companies from different countries and for companies not listed on the stock exchange. Given the scarcity of studies comparing the long-term and short-term association of variables describing the financial situation of companies with their capital structure, this study can be viewed as a prelude for further research.

\section{References}

Ang J.S., Cole R.A., Lawson D. [2010], The role of owner in capital structure decisions: an analysis of single-owner corporations, The Journal of Entrepreneurial Finance, 14(3): 1-36.

Arioglu E., Tuan K. [2014], Speed of adjustment: Evidence from Borsa Istanbul, Borsa Istanbul Review, 14(2): 126-131.

Balakrishnan S., Fox I. [1993], Asset specificity, firm heterogeneity and capital structure, Strategic Management Journal, 14(1): 3-16.

Baltagi B. [2008], Econometric analysis of panel data, John Wiley \& Sons.

Baltagi B., Griffin, J.M. [1984], Short and long run effects in pooled models, International Economic Review, 25: 631-645.

Bancel F., Mittoo U.R. [2004], Cross-country determinants of capital structure choice: a survey of European firms, Financial Management: 103-132.

Białek-Jaworska A., Nehrebecka N. [2015], Determinants of Polish Companies' Debt Financing Preferences, Social Sciences, 87(1): 10-32.

Bradley M., Jarrell G.A., Kim E. [1984], On the existence of an optimal capital structure: Theory and evidence, Journal of Finance, 39(3): 857-878. 
Brendea G. [2014], Financing behavior of Romanian listed firms in adjusting to the target capital structure, Finance a Uver, 64(4): 312.

Brennan M.J., Schwartz E.S. [1978], Corporate income taxes, valuation, and the problem of optimal capital structure, Journal of Business: 103-114.

Brounen D., De Jong A., Koedijk K. [2006], Capital structure policies in Europe: Survey evidence, Journal of Banking and Finance, 30(5): 1409-1442.

Chang Y.-K., Chou R.K., Huang T.-H. [2014], Corporate governance and the dynamics of capital structure: New evidence, Journal of Banking and Finance, 48: 374-385.

Chang X., Dasgupta S. [2009], Target behavior and financing: how conclusive is the evidence?, The Journal of Finance, 64(4): 1767-1796.

Dang V.A., Garrett I. [2015], On corporate capital structure adjustments, Finance Research Letters, 14: 56-63.

Dang V.A., Kim M., Shin Y. [2012], Asymmetric capital structure adjustments: New evidence from dynamic panel threshold models, Journal of Empirical Finance, 19(4): 465-482.

Dang V.A., Kim M., Shin Y. [2014], Asymmetric adjustment toward optimal capital structure: Evidence from a crisis, International Review of Financial Analysis, 33: 226-242.

de Haas R., Peeters H. [2004], Firms' dynamic adjustment to target capital structures in transition economies, Netherlands Central Bank, Research Department.

DeAngelo H., Roll R. [2015], How stable are corporate capital structures?, The Journal of Finance, 70(1): 373-418.

Farhat J., Cotei C., Abugri B. [2006], The pecking order hypothesis vs. the static trade-off theory under different institutional environments, preliminary draft, researchgate.net, access date: 30 September 2019.

Faulkender M., Flannery M.J., Hankins K.W., Smith J.M. [2012], Cash flows and leverage adjustments, Journal of Financial Economics, 103(3): 632-646.

Fischer O., Heinkel R., Zechner J. [1989], Dynamic capital structure choice: Theory and tests, Journal of Finance, 44(1): 19-40.

Flannery M.J., Hankins K.W. [2013], Estimating dynamic panel models in corporate finance, Journal of Corporate Finance, 19: 1-19.

Flannery M.J., Rangan K.P. [2006], Partial adjustment toward target capital structures, Journal of Financial Economics, 79(3): 469-506.

Gajdka J. [2002], Teorie struktury kapitatu i ich aplikacja w warunkach polskich, Wydawnictwo Uniwersytetu Łódzkiego, Łódź.

Graham J.R., Harvey C.R. [2001], The theory and practice of corporate finance: Evidence from the field, Journal of Financial Economics, 60(2): 187-243.

Grilliches Z., Hausman J.A. [1986], Errors in variables in panel data, Journal of Econometrics, 31: $93-118$.

Hamada R., Kane A., Marcus A.J., McDonald R.L. [1984], How big is the tax advantage to debt?, Journal of Finance, 39(3): 841-853.

Houthakker H.S. [1965], New Evidence on Demand Elasticities, Econometrica, 33: 277-288.

Huang R., Ritter J.R. [2009], Testing theories of capital structure and estimating the speed of adjustment, Journal of Financial and Quantitative Analysis, 44(2): 237-271. 
Jõeveer K. [2013], Firm, country and macroeconomic determinants of capital structure: Evidence from transition economies, Journal of Comparative Economics, 41(1): 294-308.

Kayo E.K., Kimura H. [2011], Hierarchical determinants of capital structure, Journal of Banking, Finance, 35(2): 358-371.

Klapper L.F., Sarria-Allende V., Zaidi R. [2006], A firm-level analysis of small and medium size enterprise financing in Poland, World Bank Policy Research Working Paper, 3984, August: 1-43.

Kuh E. [1959], The Validity of Cross-sectionally Estimated Behaviour Equations in Time Series Applications, Econometrica, 27: 197-214.

Leland H.E. [1994], Corporate debt value, bond covenants, and optimal capital structure, Journal of Finance, 49(4): 1213-1252.

Lemma T.T., Negash M. [2014], Determinants of the adjustment speed of capital structure: Evidence from developing economies, Journal of Applied Accounting Research, 15(1): 64-99.

Lemmon M.L., Roberts M.R., Zender J.F. [2008], Back to the beginning: persistence and the cross-section of corporate capital structure, Journal of Finance, 63(4): 1575-1608.

Lockhart B. [2014], Credit lines and leverage adjustments, Journal of Corporate Finance, 25: 274-288.

Lucas D.J., McDonald R.L. [1990], Equity issues and stock price dynamics, Journal of Finance, 45(4): 1019-1043.

Mairesse J. [1990], Time-series and cross-sectional estimates on panel data: Why are they different and why should they be equal?, in: J. Hartog, G. Ridder and J. Theeuwes (eds.), Panel Data and Labor Market Studies, North-Holland, Amsterdam: 81-95.

Matemilola B.T., Noordin B.A.A., Ngah W.A.S. W., Nassir A.M. [2015], Unobservable effects and speed of adjustment to target capital structure, International Journal of Business and Society, 16(3): 470.

Mazur K. [2007], The determinants of capital structure choice: evidence from Polish companies, International Advances in Economic Research, 13(4): 495-514.

Miao J. [2005], Optimal capital structure and industry dynamics, Journal of Finance, 60, no. 6: 2621-2659.

Mundlak Y. [1978], On the pooling of time series and cross-section data, Econometrica, 46: 69-85.

Myers S.C. [1984], The capital structure puzzle, Journal of Finance, 39(3): 574-592.

Myers S.C., Majluf N.S. [1984], Corporate financing and investment decisions when firms have information that investors do not have, Journal of Financial Economics, 13(2): 187-221.

Nivorozhkin E. [2005], Financing choices of firms in EU accession countries, Emerging Markets Review, 6(2): 138-169.

Oino I., Ukaegbu B. [2015], The impact of profitability on capital structure and speed of adjustment: An empirical examination of selected firms in Nigerian Stock Exchange, Research in International Business and Finance, 35: 111-121.

Ozkan A. [2001], Determinants of capital structure and adjustment to long run target: evidence from UK company panel data, Journal of Business Finance and Accounting, 28 (1-2): 175-198.

Öztekin Ö., Flannery M.J. [2012], Institutional determinants of capital structure adjustment speeds, Journal of Financial Economics, 103(1): 88-112. 
Pirotte A. [1999], Convergence of the static estimation toward long run effects of dynamic panel data models, Economics Letters, 53: 151-158.

Rajan R.G., Zingales L. [1995], What do we know about capital structure? Some evidence from international data, Journal of Finance, 50(5): 1421-1460.

Roberts M.R., Leary M.T. [2005], Do Firms Rebalance their Capital Structures?, Journal of Finance, 60(6): 2575-2619.

Roberts M.R., Leary M.T. [2010], The pecking order, debt capacity, and information asymmetry, Journal of Financial Economics, 95(3): 332-355.

Roodman D. [2006], How to do xtabond': An introduction to difference and system GMM in Stata, North American Stata Users' Group Meetings Working Paper, 103.

Ruiz A.U. [2016], Long run and short run components in explanatory variables and differences in Panel Data estimators, 22nd International Conference of Panel Data - Curtin Business School in Perth, Australia.

Shyam-Sunder L., Myers S. [1999], Testing static tradeoff against pecking order models of capital structure, Journal of Financial Economics, 51(2): 219-244.

Stiglitz J.E. [1973], Taxation, corporate financial policy, and the cost of capital, Journal of Public Economics, 2(1): 1-34.

Strebulaev A. [2007], Do tests of capital structure theory mean what they say?, The Journal of Finance, 62(4): 1747-1787.

Titman S., Tsyplakov S. [2007], A dynamic model of optimal capital structure, Review of Finance, 11(3): 401-451.

Unless stated otherwise all the materials are available under the Creative Commons Attribution 4.0 International license. Some rights reserved to the SGH Warsaw School of Economics. 